https://doi.org/10.48009/2_iis_2008_466-475

\title{
PRIVATE SECTOR VERSUS PUBLIC SECTOR RESEARCH ON SOFTWARE PROJECT MANAGEMENT: AN EXPLORATORY STUDY
}

\author{
Kevin Lee Elder, Georgia Southern University, kelder@georgiasouthern.edu \\ Michael R. Garman, USAF
}

\begin{abstract}
Project managers typically set three success criteria for their projects: meet specifications, be on time, and be on budget. However, software projects frequently fail to meet these criteria. Software engineers, acquisition officers, and project managers have all studied this issue and made recommendations for achieving success. But most of this research in peer reviewed journals has focused on the private sector. Private sector project success depends on many elements. Critical success factors are those factors a project manager must properly handle to avoid failure. And priorities influence which success criteria the project manager will most likely succeed in meeting. Through a survey of software project managers at two USAF software development organizations, our research discovered the following: Air Force and private sector projects share many of the same critical success factors for nonweapon systems, but there are still some sharp differences.
\end{abstract}

Keywords: Project Management, Public Sector, Critical Success Factors, and Software Development

\section{INTRODUCTION}

Professional project management deals with multimillion dollar endeavors that can take years to finish. Space programs, buildings, bridges, dams, pharmaceutical products, jets, and weapon systems are all traditional examples of programs that require project management. During the last three decades, software projects have joined this group and challenged project managers with their intangible existence and complexity.

The proper management of software projects makes the difference in achieving the three traditional success criteria: completing the project on budget, implementing the project on schedule, and fulfilling all of the users' specifications. Nonetheless, project success is a difficult outcome to nail down. The user of this software product must be satisfied with the software product and use it before recognizing it as a success, regardless of how well the project manager achieves other criteria. The user's attitude, involvement, and participation with the project's development greatly influence satisfaction. Likewise, additional success factors are critical in reaching the traditional success criteria (such as support from senior management, effective management of risk, and effective leadership).

Due to difficulties in attaining these criteria, literature has noted many projects that have failed some or all of these criteria. For example, the Standish Group Report [17] discussed their research for 365 companies on 8,380 software projects. $31 \%$ of the projects were cancelled. $53 \%$ of the completed projects were $189 \%$ over budget. And only $16 \%$ of the completed projects actually finished on time and on budget.

Meanwhile, the Department of Defense is acquiring and maintaining weapon systems that depend on these software projects to be successful (Table 1). For example, the defunct Crusader Artillery used 1,800,000 lines of code, and the F-22 uses 1,960,000 lines of code. The success of these software systems impact the survival of Americans and mission accomplishment. Likewise, successful nonweapon software systems increase the military's productivity and communications capabilities. For example, the USAF plans to connect 700 software systems with the Air Force Portal so members have access to all the information they require for their duties.

\section{Table 1}

Weapon System Software Sizes

\begin{tabular}{lc}
\hline \multicolumn{1}{c}{ Weapon System } & $\begin{array}{c}\text { Source Lines of } \\
\text { Code }\end{array}$ \\
\hline M1 Tank & 600,000 \\
Scout / Cav & $1,000,000$ \\
M2 Infantry Fighting Vehicle & $1,560,000$ \\
Crusader Artillery & $1,800,000$ \\
F-22 & $1,960,000$ \\
Aegis & $2,840,000$ \\
\hline
\end{tabular}

Note. From "Curing the Software Requirements and Cost Estimating Blues," by M. Nelson, J. Clark, and M. A. Spurlock, 1999, Program Manager, 17, p. 54. 


\section{Problem Statement}

In response to these stories of software crises and project failures, many professional journals (such as Cross Talk for Department of Defense software engineers) and peer-reviewed literature have published articles on software projects and project management in general. However, there is little published research that focuses specifically on software projects within the military and federal government; practically all literature deals with software projects in the private sector. Military project management for software development and maintenance is a highly relevant issue because the military has had an equally difficult time with it as the private sector. For example, the Air Force spent $\$ 60$ million and 5 years on developing a new personnel information software system. In May of 2001, the Air Force launched this new system and immediately started having problems, such as preventing new military members from receiving pay. A year later, the software system still suffered glitches. At the Air Force Personnel Center's website http://www.afpc.randolph.af.mil/modern/, technicians reported correcting 4,944 problems with the personnel system as of August 19th, 2002. But on the same day, they also reported 461 more complaints and bugs to pursue. By 2004, the U.S. Army began designing an even larger software system modeled off of the Air Force system at an expense of $\$ 500$ million.

Table 2

Weapon System Software Dependencies

\begin{tabular}{ccc}
\hline $\begin{array}{c}\text { Weapon } \\
\text { System }\end{array}$ & Year & $\begin{array}{c}\text { Percent of } \\
\text { Functions } \\
\text { Performed in } \\
\text { Software }\end{array}$ \\
\hline F-4 & 1960 & 8 \\
A-7 & 1964 & 10 \\
F-111 & 1970 & 20 \\
F-15 & 1975 & 35 \\
F-16 & 1982 & 45 \\
B-2 & 1990 & 65 \\
F-22 & 2000 & 80 \\
\hline
\end{tabular}

Note. From "Curing the Software Requirements and Cost Estimating Blues," by M. Nelson, J. Clark, and M. A. Spurlock, 1999, Program Manager, 17, p. 55.
Our military aircraft are also increasingly becoming dependent on software. As Table 2 shows, in 1960, only $8 \%$ of the F-4's functions depended on software. But within 10 years, $20 \%$ of the F-111's functions depended on software, and, in 1990, the B-2's functions were software dependent by $65 \%$.

These weapon systems and software systems are just several of many software products that the Air Force depends on for mission accomplishment. Consequently, research on the generalizability of private sector research to the public sector can help confirm Air Force current practices or identify the necessity for different methodologies for software project management in the military.

\section{Research Question and Investigative Questions}

Because the Air Force is subject to the same software project management problems as the private sector, the Air Force would benefit from research generalizable to the military for its current and future software project management endeavors. However, after conducting an exhaustive review of the literature, we were unable to find any substantive research on this subject regarding military software project management. Therefore, we conducted an exploratory study to learn about military software project management and break new ground in this field. The overall research question asked, "How do the success factors in software project management for the Air Force differ (if at all) from the private sector?"

This question covered a very diverse topic, considering all the possible factors that can go into successful project management. Therefore, the only factors studied were those under the project manager's control (i.e. no environmental factors, which are outside of the project manager's control). One of the three investigative questions narrowed the scope of this paper:

Are the critical success factors for Air Force software projects different from private sector projects?

This investigative question required a variety of data to answer. Software project managers from two Air Force units, "Organization Alpha" and "Organization Bravo," responded to a questionnaire to provide data for the investigative questions. Both Organizations Alpha and Bravo develop and sustain software for the Air Force, either by developing in-house, adapting commercial off the shelf products, or supervising contracted out work. Project managers used a survey 
to list all the factors that are critical to project success. This data was then analyzed through comparison with private sector research and statistical methods.

\section{LITERATURE REVIEW}

Researchers and subject matter experts have identified differences in methodology between public and private software acquisitions. However, this study was unable to find any research specifically on differences between private and public sector project management. Literature indicates how various factors influence the perceived success of projects (Table 3).

Table 3

Definitions of Constructs

\begin{tabular}{ll}
\hline Construct & Definition \\
\hline Communication & $\begin{array}{l}\text { The provision of an appropriate network and necessary data to all key acto } \\
\text { in the project implementation, including the user and customer [15]. }\end{array}$ \\
\hline Critical Success Factors & $\begin{array}{l}\text { The few factors that will ensure success in a particular business area if the } \\
\text { manager gives them the necessary attention. Likewise, if these factors are } \\
\text { disregarded, the endeavor is bound to fail [14]. }\end{array}$
\end{tabular}

\begin{tabular}{ll} 
Customer Satisfaction & $\begin{array}{l}\text { The product satisfies all needs and expectations and the user is pleased with } \\
\text { it, despite whether it is on time, on budget, and fulfills all specifications } \\
\text { [15]. }\end{array}$ \\
\hline Consists of both user satisfaction and the traditional success criteria [13]. \\
\hline Project Success
\end{tabular}

\section{Differences Between Private Sector and Public Sector MIS}

Previous research suggests substantive differences between public and private sector management information systems [4, 5, and 6]. In regard to software project management and related acquisitions, Bozeman and Bretschneider [4] note public sector MIS "requires a protracted period of testing and prototype development." Strong accountability is necessary because government software projects are open to public scrutiny. And
Bretschneider [5] adds that private sector organizations evaluate software acquisitions by the economic efficiency of their performance. However, public sector software acquisitions are strongly influenced by procedural equity such as acquisition regulations, government contracting rules, and Department of Defense (DoD) standards. In a review of DoD software acquisitions, Jones [10], a subject matter expert, anecdotally notes even more differences in the public sector. In addition to a highly regulated contractual procurement process, he also observes that military procurement frequently 
has litigation challenging the successful bidder (with side-effects like delays in the project schedule) and extensive oversight and control requirements (resulting in documentation three times larger than equivalent civilian projects).

On the other hand, Devlin and Royce [8] comment in an Air Force software acquisition book that "many commercial practices are inappropriate to most DoD software (the glaring exception is DoD's MIS systems which only differ by perhaps their scale)."

These differences in MIS and software acquisition procedures and rules begs the question whether public sector project management of software is distinctly different from the private sector. If it is, then military software project management may require a different form of methodology from what the private sector uses. This research sought to study common constructs in project management within two Air Force software developing organizations that might question or affirm the generalizability of private sector research on those two Air Force organizations.

\section{Critical Success Factors Research}

While many factors contribute to a project's successful completion, only some of these factors are under the project manager's control. This research studied those non-environmental factors that are most critical to project success. These factors influence the achievement of customer satisfaction and completing software projects on time, on budget, and within specifications. The literature review covers the following constructs toward achieving project success: critical success factors (CSFs), user interaction and customer satisfaction, and success criteria and priorities.

J. F. Rockart [14] defines critical success factors (CSFs) as the few factors that will ensure success in a particular business area if the manager gives them the necessary attention. Likewise, if these factors are disregarded, the endeavor is bound to fail. Boynton and Zmud [3] researched the CSF construct through case studies and concluded that it is a valid construct worthy of further research. Their research indicates that two CSFs are managerial support and "a positive relation and a meaningful dialogue with users." Various researchers have since studied CSFs for project management [7, 9, 12, and 18]. Each researcher has concluded with slightly different factors, but all of them have found the user of the project to be a factor of success.
Dobbins [9] notes the scarcity of articles on military project management and then details critical success factors for defense acquisition programs. $\mathrm{He}$ surveyed two groups of defense program managers: those who worked on software for weapon systems and those who worked on software for information systems. Delano [7] made a similar survey for the CSFs of defense acquisitions (but not specifically software). Both studies indicate a strong user relationship was one of the top six factors. Jones [10], a subject matter expert, observed twelve CSFs while judging 16 of the best DoD software projects for 2001. Beyond these two, the majority of project management articles in peer-reviewed journals deal with the private sector.

Pinto and Slevin [12] initially constructed their list of 10 CSFs from a card-based survey of MBA students on important factors for successful projects of all types. Since then, they have repeatedly tested and verified their CSFs in subsequent studies [12, 13]. Their studies indicate three factors that particularly influence obtaining customer satisfaction: (a) client consultation (actively listening to the client and discussing realistic expectations), (b) client acceptance (convincing the client the project is worth the expense and trouble of difficulties), and (c) communication (updating the client, providing feedback, asking for input). Slevin and Pinto [15] designed a survey to measure how well a project manager handled the $10 \mathrm{CSF}$ on a current project. Subsequently, Pinto and Slevin [13] tested an addition to the questionnaire to evaluate the success of a project from the project manager's perceptions. Success was partly based off of the elicitation of a positive user attitude toward the final product.

White and Fortune's study [18] is one of the most recent studies on CSFs. They surveyed project managers from 88 different industries, but only 5 worked in defense. Of the 236 respondents, 60 managed an "information technology" project, 26 had a "software development" project, and 7 had dealt with a software project on "Year 2000 compliance." White and Fortune's questionnaire offered a list of 19 CSFs taken from literature (including Pinto and Slevin, [12]). They expanded the list to 23 when some of the respondents offered additional CSFs that literature had not yielded. Their results indicate user commitment to the project is among the top five CSFs. Atkinson [1] argues that researchers should review the traditional success criteria of projects, namely, (a) being on time, (b) on budget, and (c) meeting product specifications. He said these three make up the Iron Triangle and that projects seem to frequently fail because these criteria for success are 
inadequate; they do not properly describe standards for judging a successful project. Success criteria should adapt to the priorities of each project. For example, life critical systems (such as military fighter jet software) should have quality as the overriding criteria. Time and cost are secondary issues in this case.

\section{RESEARCH METHODOLOGY}

Software project managers from Organization Alpha and Organization Bravo responded to an online questionnaire. Both Alpha and Bravo develop and maintain software for the Air Force. Both operate at Level 3 on the Software Development-Capability Maturity Model. They have documented, standardized, and defined their work processes in management and software engineering so that results are repeatable and can be analyzed to some basic extent. Alpha has approximately 565 civilians, 178 officers, and 678 enlisted. Bravo has approximately 546 civilians, 29 officers, and 28 enlisted. Most software project managers and program managers are civilians and officers, while most of the code programmers and technology experts are enlisted and civilians.

Commanders of both organizations endorsed the invitation to take this questionnaire and emailed the invitation to all of their software program managers and project managers. The questionnaire was available online from December 15th to January 20th. The commanders sent reminders on January 13th. Stanton [16] indicates measurement equivalence between internet questionnaires and traditional paper versions. The questionnaire refers to software in general because the project managers dealt with a variety of software products, each with different levels of complexity and source lines of code. The respondents selected the 10 factors they considered most critical for project success from a list of 23 taken from literature on project management [18].

\section{DATA ANALYSIS}

For the investigative question, the nonparametric data was examined with Kendall's and Spearman's Rank Correlation methods. Each respondent selected 10 CSFs out of a list of 23 possible. A rank ordering of CSFs was derived from adding up how many times each CSF was selected. Kendall's and Spearman's Rank Correlation methods were used to detect any statistically significant differences between the rank orders of this study's results and White and Fortune's
[18]. These methods use a null hypothesis and an alternate hypothesis in a two-tailed test:

$\mathrm{Hn}: \mathrm{r}=0$.

Ha: $r \neq 0$.

Spearman's rank correlation coefficient, $r$ (Spearman's rho), indicates how well the two rank orderings correlate. A perfect positive correlation would be $r=1$. A perfect negative correlation would be $r=-1$. As the coefficient of $r$ approaches 0 , the correlation decreases to the point of 0 , in which there is absolutely no correlation.

Kendall's method is intended for a smaller number of responses (fewer than 10). Kendall's method thus works well for deeper analysis of the data for demographic groupings within the larger respondent population of 64 (e.g.: there were 9 project managers in charge of projects developed by contractors). By contrasting the results of this study with White and Fortune's results, this study identified differences between Air Force software project managers perceived CSFs and the private sector. Comparisons were also made between cross sections of the data for demographic groupings.

By comparing data within demographic groupings, this study sought to infer more than the cumulative average. These demographic groupings break respondents up by service (military and civil service), project role (project manager and program manager), veteran experience in software engineering and/or project management $(10>x \geq 5$ years and $x \geq 15$ years), type of project (sustaining a legacy system and developing a new product), primary developer (government, commercial off-the-shelf, and contractor), and the project's status (good and critical).

White and Fortune [18] include past experience as one of the CSFs that other researchers had identified. Therefore, project manager experience was used as a discriminator to see how it affected the other variables. Five years is the baseline because the Project Management Institute requires a person (among other criteria) to have at least 3 years of experience managing a project to apply for the association's certification as a project manager. As such, 5 years was a conservative baseline to expect project managers to make good decisions in project management through lessons learned from experience. The 5 to 10 year group of respondents is contrasted with the 15+ year respondents to look for any conspicuous differences between the two that might not be visible by also including the 10 to 15 year group. 
The respondents provided a variety of data for the questionnaires. A straightforward look at the data indicates answers to this exploratory study's investigative question on CSFs. However, even more can be inferred by examining the data through cross sections of the respondents. The questionnaire invitation was sent to 214 people whom Organization Alpha and Organization Bravo classified as software project managers. There were 71 respondents, which yielded a $33.2 \%$ response rate. Six respondents only answered half the questionnaire, and they are consequently not included in the data analysis for the second and third investigative questions. Likewise, one respondent invalidated his answers by stating he was not knowledgeable enough to properly answer the questions. Investigative Question: Are the critical success factors for Air Force software projects different from private sector projects?

The rank comparison between the research results and White and Fortune's data [18] using Kendall's tau correlation and the Spearman rank order correlation revealed a positive correlation between the pair of rank orderings (Table 4). The model was statistically significant. However, Spearman's correlation coefficient of 0.547 indicates the correlation is not perfect and that the surveyed project managers had other CSFs than the private sector. The public and private sector agreed on the top seven CSFs, but not in the same order (Table 5).

\begin{tabular}{lc}
\hline $\begin{array}{l}\text { Table } 4 \\
\text { Rank Comparison between Research Results and } \\
\text { White and Fortune [18] }\end{array}$ \\
\hline Method & $\begin{array}{c}\text { Correlation } \\
\text { Coefficient } \\
\end{array}$ \\
Kendall's tau-b & 0.436 \\
Spearman's rho & 0.547 \\
\hline Note. $p<0.05$ &
\end{tabular}

Table 4

Rank Comparison between Research Results and White and Fortune [18]

Note. $p<0.05$

Table 5

Rank Comparison Between CSFs, Research Results and White and Fortune (2002)

\begin{tabular}{|c|c|c|c|c|}
\hline \multirow[b]{2}{*}{ CSFs } & \multicolumn{2}{|c|}{ Rank } & \multicolumn{2}{|c|}{$\begin{array}{c}\text { \% of Respondents Who } \\
\text { Selected this CSF } \\
\end{array}$} \\
\hline & $\begin{array}{l}\text { Research } \\
\text { Results }\end{array}$ & $\begin{array}{l}\text { White \& } \\
\text { Fortune [18] }\end{array}$ & $\begin{array}{l}\text { Research } \\
\text { Results }\end{array}$ & $\begin{array}{l}\text { White \& } \\
\text { Fortune [18] }\end{array}$ \\
\hline Adequate funds/resources & 1 & 4 & 93.8 & 69.5 \\
\hline Clear goals/objectives & 2 & 1 & 87.5 & 87.3 \\
\hline Realistic schedule & 3 & 2 & 85.9 & 78.4 \\
\hline End user commitment & 4 & 5 & 79.7 & 67.4 \\
\hline Clear communication channels & 5 & 6 & 71.9 & 61.0 \\
\hline Having access to innovative/talented people & 6 & 20 & 64.1 & 3.4 \\
\hline Support from senior management & 7 & 3 & 54.7 & 74.6 \\
\hline Effective management of risk & 8.5 & 13.5 & 53.1 & 49.6 \\
\hline Support from stakeholder(s)/champion(s) & 8.5 & 21.5 & 53.1 & 1.3 \\
\hline Effective leadership/conflict resolution & 10 & 7 & 50.0 & 58.5 \\
\hline Having a clear project boundary & 11 & 23 & 40.6 & 0.8 \\
\hline Effective team building/motivation & 13.5 & 13.5 & 34.4 & 49.6 \\
\hline Flexible approach to change & 13.5 & 9 & 34.4 & 56.4 \\
\hline Having relevant past experience & 13.5 & 21.5 & 34.4 & 1.3 \\
\hline Recognizing complexity & 13.5 & 10.5 & 34.4 & 51.3 \\
\hline Effective monitoring and feedback & 16 & 8 & 29.7 & 57.2 \\
\hline Training provision & 17 & 15 & 25.0 & 41.5 \\
\hline Taking account of past experience & 18 & 10.5 & 18.8 & 51.3 \\
\hline Taking account of external influences & 19 & 12 & 15.6 & 50.8 \\
\hline Considering multiple views of project & 20.5 & 19 & 9.4 & 19.9 \\
\hline Provision of planning and control systems & 20.5 & 17 & 9.4 & 37.3 \\
\hline Contextual awareness & 22 & 16 & 7.8 & 39.8 \\
\hline Appreciating the effect of human error & 23 & 18 & 6.3 & 22.5 \\
\hline
\end{tabular}


Table 5 displays a complete list of rankings between this study's results and the results of White and Fortune [18]. The sharp difference in lower ranked factors is most notable in the CSFs ranked 6, 8.5 (had a tie), and 11 by the Air Force software project managers. The private sector project managers correspondingly ranked them $20,21.5$, and 23 . The percent of project managers selecting each CSF emphasized the distinct difference in choice between private and public sector respondents. For example, for the CSF of "support from stakeholders and champions," $53.1 \%$ of Air Force project managers selected it, while only $1.3 \%$ of private sector project managers selected it.
The demographic groups had very similar rankings to the average (Table 6). The groups that were compared with each other strongly agreed on the ranking. Surprisingly, the Good Projects and Critical Projects had a very high Spearman's rho of 0.91 . This indicates the software project managers for both successful and unsuccessful projects agree on CSFs, but the successful project managers are better at applying those CSFs. Likewise, the newer project managers ( 5 up to 10 years of experience) and more experienced ones (15+ years) strongly agreed on CSFs (0.94) but the newer project managers still had a much higher failure rate.

Table 6

Rank Correlation Among Groups

\begin{tabular}{llcc}
\hline Compared Rankings & & Spearman's rho & Kendall's tau-b \\
\hline Research & White \& Fortune, 2002 & 0.55 & 0.44 \\
\hline $5 \leq \mathrm{x}<10$ Years & $15 \leq \mathrm{x}$ Years & 0.94 & 0.82 \\
Good Project & Critical Project & 0.91 & 0.77 \\
\hline Project Manager & Program Manager & 0.86 & 0.72 \\
Military & Civil Service & 0.84 & 0.70 \\
Sustainment & New Development & 0.81 & 0.61 \\
GOTS & COTS & 0.85 & 0.70 \\
GOTS & Contractor Developed & 0.86 & 0.70 \\
COTS & Contractor Developed & 0.66 & 0.54 \\
\hline
\end{tabular}

Note. GOTS stands for "government developed." COTS stands for "commercial off the shelf." $p<0.05$

Table 7

CSF Comparison Between Sustaining A Legacy System and New Start Software Development

\begin{tabular}{|c|c|c|c|c|c|c|}
\hline \multirow[b]{2}{*}{ CSFs } & \multicolumn{2}{|c|}{ Rank $_{\text {New }}$} & \multicolumn{2}{|c|}{$\begin{array}{c}\% \text { of Respondents } \\
\text { New }\end{array}$} & \multicolumn{2}{|c|}{$\begin{array}{c}\text { Raw Data, \# of } \\
\text { Respondents } \\
\text { Selecting this CSF } \\
\text { New }\end{array}$} \\
\hline & Sustain & Start & Sustain & Start & Sustain & Start \\
\hline Effective management of risk & 7 & 10.5 & 63 & 41 & 22 & 7 \\
\hline Having a clear project boundary & 9.5 & 19.5 & 49 & 18 & 17 & 3 \\
\hline Effective leadership/conflict resolution & 11 & 5.5 & 46 & 65 & 16 & 11 \\
\hline Effective team building/motivation & 12 & 17.5 & 43 & 24 & 15 & 4 \\
\hline Having relevant past experience & 13 & 17.5 & 40 & 24 & 14 & 4 \\
\hline Taking account of past experience & 18 & 14 & 11 & 29 & 4 & 5 \\
\hline Taking account of external influences & 22 & 14 & 3 & 29 & 1 & 5 \\
\hline Appreciating the effect of human error & 23 & 19.5 & 0 & 18 & 0 & 3 \\
\hline
\end{tabular}


Differences also materialized between project managers responsible for sustaining a legacy system (software maintenance) and project managers developing new software (Table 7). 29\% of the new start respondents valued taking account of past experience and taking account of external influences, while $11 \%$ of the respondents for sustainment valued past experience and only 3\% accounted for external influences as a CSF.

As noted earlier, the project managers with 5 to 10 years of experience had the highest percentage of failed projects out of all the 5 year groups, while the project managers with 15 and more years of experience had the highest percentage of successful projects. Surprisingly, a comparison between these two groups reveals a very strong similarity in the percentage of respondents choosing CSFs (Table 8). The differences between these two groups appear to be insignificant. The one CSF they differ on is training provisions, with $32 \%$ of respondents of $15+$ years choosing it, and only $8 \%$ of project managers with 5 up to 10 years of experience choosing it.
This strong agreement in CSFs possibly indicates both groups of project managers have had the same project management and software engineering education during the last five years. In which case, the $15+$ year group could be making wiser use of the CSFs in contrast to the less experienced group.

Similar to the different groups of experience, the project managers of successful projects and critical projects have a very close percentage of respondents selecting the same CSFs (Table 9). These project managers may have also had different ways of using the CSFs, resulting in different results. One distinct difference exists in building an effective team, which $55 \%$ of the successful respondents chose versus only $25 \%$ of the critical respondents. The successful respondents, on the other hand, considered support from senior management to be less important (36\%), while $67 \%$ of the critical respondents chose it as a CSF.

\section{Table 8}

CSF Comparison Between Project Managers with 5 to 10 and 15+ Years of Experience

\begin{tabular}{|c|c|c|c|c|c|c|}
\hline CSFs & \multicolumn{2}{|c|}{ Rank } & \multicolumn{2}{|c|}{$\%$ of Respondents } & \multicolumn{2}{|c|}{$\begin{array}{c}\text { Raw Data, \# of } \\
\text { Respondents } \\
\text { Selecting this CSF }\end{array}$} \\
\hline Clear goals/objectives & 1.5 & 2.5 & 100 & 84 & 13 & 16 \\
\hline End user commitment & 1.5 & 4.5 & 100 & 74 & 13 & 14 \\
\hline Realistic schedule & 3 & 2.5 & 92 & 84 & 12 & 16 \\
\hline $\begin{array}{l}\text { Adequate funds/resources } \\
\text { Having access to }\end{array}$ & 4 & 1 & 85 & 100 & 11 & 19 \\
\hline innovative/talented people & 5 & 4.5 & 77 & 74 & 10 & 14 \\
\hline $\begin{array}{l}\text { Clear communication channels } \\
\text { Effective leadership/conflict }\end{array}$ & 7 & 6 & 62 & 68 & 8 & 13 \\
\hline $\begin{array}{l}\text { resolution } \\
\text { Support from }\end{array}$ & 7 & 7.5 & 62 & 58 & 8 & 11 \\
\hline $\begin{array}{l}\text { stakeholder(s)/champion(s) } \\
\text { Support from senior }\end{array}$ & 7 & 9 & 62 & 53 & 8 & 10 \\
\hline management & 9 & 7.5 & 54 & 58 & 7 & 11 \\
\hline Effective management of risk & 10 & 14.5 & 46 & 37 & 6 & 7 \\
\hline Training provision & 22 & 16.5 & 8 & 32 & 1 & 6 \\
\hline
\end{tabular}

Note. CSFs are ordered for project managers with 5 up to 10 years of experience. 
Table 9

CSF Comparison Between Successful and Critical Projects

\begin{tabular}{|c|c|c|c|c|c|c|}
\hline \multirow[b]{2}{*}{ CSFs } & \multicolumn{2}{|c|}{ Rank } & \multicolumn{2}{|c|}{$\%$ of Respondents } & \multicolumn{2}{|c|}{$\begin{array}{c}\text { Raw Data, \# of } \\
\text { Respondents } \\
\text { Selecting this CSF }\end{array}$} \\
\hline & Success & Critical & Success & Critical & Success & Critical \\
\hline Adequate funds/resources & 1 & 3 & 100 & 88 & 22 & 21 \\
\hline Clear goals/objectives & 2 & 3 & 86 & 88 & 19 & 21 \\
\hline Realistic schedule & 3 & 1 & 82 & 92 & 18 & 22 \\
\hline Clear communication channels & 4 & 5 & 77 & 75 & 17 & 18 \\
\hline $\begin{array}{l}\text { Having access to innovative/talented } \\
\text { people }\end{array}$ & 5 & 6 & 73 & 71 & 16 & 17 \\
\hline End user commitment & 6 & 3 & 68 & 88 & 15 & 21 \\
\hline Effective leadership/conflict resolution & 7 & 9 & 59 & 58 & 13 & 14 \\
\hline Effective management of risk & 8.5 & 10 & 55 & 46 & 12 & 11 \\
\hline $\begin{array}{l}\text { Effective team building/motivation } \\
\text { Support from }\end{array}$ & 8.5 & 15 & 55 & 25 & 12 & 6 \\
\hline stakeholder(s)/champion(s) & 11 & 7.5 & 41 & 67 & 9 & 16 \\
\hline Support from senior management & 13.5 & 7.5 & 36 & 67 & 8 & 16 \\
\hline
\end{tabular}

Note. CSFs are ordered for successful projects.

\section{CONCLUSIONS}

This exploratory study began with the following investigative question:

Are the critical success factors for Air Force software projects different from private sector projects?

The questionnaire results indicate private sector research on these constructs is mostly generalizable to the two surveyed Air Force units, specifically Organization Alpha and Organization Bravo. Although researchers have found public sector differences in the procedures, contracting, and documentation of software acquisitions, project management itself is not much different from the private sector for these two organizations. Therefore, many of the private sector advances in project management should be applicable to these Air Force organizations, as well.

The investigative question had an answer that suggests a partial difference between the private sector and the two Air Force organizations. Although the Air Force software project managers and private sector project managers shared many of the same CSFs, there were still some distinct differences. These differences probably come from the different organizational cultures and environments. For example, Air Force project managers may have highly valued "having access to innovative/talented people" because these people are a scarce resource in the Air Force. Many innovative/talented people periodically move to another assignment to progress in their careers or leave the military to work elsewhere. On the other hand, private sector managers have the freedom to hire innovative/talented people for competitive salaries and then just as easily fire them when the economy goes into a recession. So, Air Force project managers must value the people they have, while private sector managers may consider them to be a dime a dozen.

For the practitioner, these results provide information to make better decisions. For example, the necessity to balance the trade-offs of not reaching all goals but still producing a software product that both the customer and user will accept and be satisfied with. Good user interaction throughout the life cycle can strengthen user satisfaction. Consequently, the two Air Force organizations may desire to make user interaction into mandatory policy. And this research revealed which CSFs are valued most by the software project managers of Alpha and Bravo. With these CSFs in mind, software project managers for these organizations can allocate their attention appropriately to these factors as they progress toward a successful project. 
For academics, this research explored a topic that has many precedents in the private sector and no precedents in the public sector, specifically software development and maintenance within Alpha and Bravo. More and more students are going to work in the public sector and the research and teaching done should reflect the differences between the public and private sectors. This study can be a founding stone for future research that explores differences in the Critical Success Factors (CSFs). Future research could also quantify the relationships between CSFs and project success and test the causative nature of the correlations that this study found.

\section{REFERENCES}

1. Atkinson, R. (1999). Project management: Cost, time and quality, two best guesses and a phenomenon, its time to accept other success criteria. International Journal of Project Management, 17, 337-342.

2. Barki, H., \& Hartwick, J. (1989). Rethinking the concept of user involvement. MIS Quarterly, 13, 53-63.

3. Boynton, A. C., \& Zmud, R. W. (1984). An assessment of critical success factors. Sloan Management Review, 25, 17-27.

4. Bozeman, B., \& Bretschneider, S. (1986). Public management information systems: Theory and prescription. Public Administration Review, 46, 475-487.

5. Bretschneider, S. (1990). Management information systems in public and private organizations: An empirical test. Public Administration Review, 50, 536-545.

6. Caudle, S. L., Gorr, W. L., \& Newcomer, K. E. (1991). Key Information Systems Management Issues for the Public Sector. MIS Quarterly, 15, 171-188.

7. Delano, K. J. (1998). Identifying factors that contribute to program success. Acquisition Review Quarterly, 5, 35-49.

8. Devlin, M., \& Royce, W. (1994). Improving software economics in the aerospace and defense industry. Guidelines for successful acquisition and management of software intensive systems: Vol. 1 (pp. 9-93). Department of the Air Force: Software Technology Support Center.
9. Dobbins, J. H., \& Donnelly, R. G. (1998). Summary research report on critical success factors in federal government program management. Acquisition Review Quarterly, 5, 61-81.

10. Jones, C. (2002). Defense software development in evolution. CrossTalk: The Journal of Defense Software Engineering, 9 (Nov), 26-29.

11. Nelson, M., Clark, J., \& Spurlock, M. A. (1999). Curing the software requirements and cost estimating blues. Program Manager, 28, 54-60.

12. Pinto, J. K., \& Slevin, D. P. (1987). Critical factors in successful project implementation. IEEE Transactions on Engineering Management, 34, 22-27.

13. Pinto, J. K., \& Slevin, D. P. (1988). Project success: Definitions and measurement techniques. Project Management Journal, 19, 6772.

14. Rockart, J. F. (1979). Chief executives define their own data needs. Harvard Business Review, 57, 81-93.

15. Slevin, D. P., \& Pinto, J. K. (1986). The project implementation profile: New tool for project managers. Project Management Journal, 17, 5770 .

16. Stanton, J. M. (1998). An empirical assessment of data collection using the Internet. Personnel Psychology, 51, 709-725.

17. The Standish Group. (1995). The Standish Group report. Retrieved 22 Nov 02, from http://www.scs.carleton.ca/ beau/PM/StandishReport.html

18. White, D., \& Fortune, J. (2002). Current practice in project management -- An empirical study. International Journal of Project Management, 20, $1-11$.

19. Zmud, Bob. (1995). MISQ central: Nature of topics. Retrieved 10 Feb 03, from http://www.misq.org/archivist/vol/no19/issu $\underline{\text { e2/edstat.html\#topics }}$ 